\title{
Mathematics, chemistry and science connection as a basis of scientific thinking
}

\author{
Matúš Ivan ${ }^{1 \mathrm{a}}$; and Renata Šulcová ${ }^{1}$ \\ ${ }^{1}$ Charles University, Faculty of Science, Department of Teaching and Didactics of Chemistry, Prague, \\ Czech Republic
}

\begin{abstract}
Scientific thinking is a basic skill that can support problemsolving of interdisciplinary tasks in science. Our research is leading us to creation of materials and resources that will support this interdisciplinary approach to education. The research includes interviews with high-school teachers of mathematics, chemistry and science, item analysis of extensive testing of knowledge and skills of high school students in chemistry in Czech Republic, follow-up survey of students' problem-solving processes in tasks requiring the use of combined knowledge of mathematics and chemistry and the creation of educational materials. The article contains a few examples of proposed educational materials. The effectiveness of created materials is verified in high-schools. Students have got the most difficulties applying algebraic calculations in chemistry, using proportions, solving equations, expressing the unknown, the spatial imagination, geometry and stereometry and the resulting arrangement of atoms and shapes of molecules, chemical analytical tasks with logical thinking, interpretation of information from graphs and tables, plotting measured values into graphs and statistical evaluation.
\end{abstract}

Keywords: Scientific thinking; high-school teachers; interview

\section{Introduction}

It is very difficult for the students to comprehend phenomena in chemistry if they lack proper mathematical apparatus. It is also not very simple to show the students practical applications of theoretical mathematical knowledge without referring to natural sciences, especially chemistry and physics.

This problem could be solved by leading the students towards scientific thinking. Scientific thinking could be defined as knowledge seeking [1]. This definition encompasses any instance of purposeful thinking that has the objective of enhancing the seeker's knowledge. One consequence that follows from this definition is that scientific thinking is a skill that the students can gain. This skill can be referred to as scientific understanding. When conditions are favourable, the process of scientific thinking may lead to scientific

\footnotetext{
a Corresponding author: ivanma@natur.cuni.cz
} 
understanding as its product. Indeed, it is the desire for scientific understanding - for explanation - that drives the process of scientific thinking [1].

\section{Theoretical background of research}

\subsection{Experts' opinions}

The problems of interdisciplinarity in science subjects and mathematics have been mentioned in many research publications around the world. Authors of these publications are considered to be specialists on subject didactics, they are mostly academic educators, education researchers and high-school teachers of not only natural science subjects. The sources for solving the indicated problems can be found in statements of renounced specialists in science and education.

Mathematician, university educator and academic researcher Jindřich Bečvář: [2]: "Many people are convinced that they do not need the mathematics in their everyday life. The partial reasons for this are overuse of technologies in daily life and overall atmosphere in the society. It is common to emphasize the importance of mathematics and science in many curricular documents and development plans. In spite of this the reality of education is very different because mathematics and science 'do not bring any direct economic effect'. The change in this situation depends on teachers - their qualification, methods of education and sufficient amount of appropriate educational materials."

Educationalist, university educator and chemist Vincentas Lamanauskas [3]: "One of the most probable causes of such situation is, that at school it is not shown or (insufficiently shown) the importance of science and technologies for future career possibilities. Why isn't this shown? Again, a lot of things determine such situation. First of all, science subjects and especially math are taught at school referring to formulas, theorems, blindly following the textbooks. Apparently, there is a lack of practical examples, real situations and problem solutions. It is understandable, that this requires much bigger resources - both material and intellectual. Thus, it is necessary to increase the possibilities for students to get acquainted with the practical appliance of sciences and math.

The problem is that teachers usually work individually; there is little of integrated activity. A wider and deeper collaboration is noticed in the science teachers' group. Math and science subject teachers collaborate much less."

University educators: Sedat Karaçam, Volkan Bilir, Azize Digilli Baran [4] "Nowadays, since the importance scientific activities and knowledge are increasing, enhancing students' scientific process skills and epistemological beliefs are more important than before. In this view, science curriculums have been revised to enhance students' scientific process skills, views about nature of science and scientific knowledge in several countries."

University educator, chemistry didactic Małgorzata Nodzyńska [5]: "Recently, the graphical communication has been essential part of all information surrounding us every day. It is necessary to consider whether the graphical information and visualisation (not only in science) is really providing simplification for understanding of messages. Not all of the people are able to comprehend the meaning of visual information without former experience. When we consider the chronology of learning through images, the older experience with graphical information is always stronger than the new one. This is the reason why even the first visualisations of the phenomenon must be factually correct."

University educator, chemist, chemistry didactic Martin Bílek [6]: "Visual perception, processing of visual information and creation of adequate conceptions in students' minds are essential parts of science education. Functional, visual and graphical literacy, modelling and visualisation in chemistry, education based on observation, measuring, experimenting, and data evaluation represent connection of mathematics and science, 
especially chemistry. However in reality of our school system the transmissive approaches dominate over the constructivism. Since the end of the $20^{\text {th }}$ century many educational studies including educational materials have been created for more active approach to education (problem solving, constructivism, project-based education and inquiry-based science education - IBSE)."

Mathematician, university educator, psychologist Alena Šarounová [7]: "Intentional teaching in school is mostly performed using speech and images. The ability to comprehend and extract the information from the visual elements of education (models, images and schematics) and to understand the meaning of symbolic language in these aids is commonly referred to as symbolic function of a brain. We have to teach our students how to read and comprehend the images (this is not very common in our schools)."

\subsection{Conclusions from literature search}

We can conclude that scientific thinking and visual literacy skills are the main tools for comprehension and understanding the science in general. These skills cannot be constructed and properly used without adequate knowledge of mathematics. The mathematical theories can be simultaneously demonstrated on phenomena from natural sciences. We can demonstrate the interdisciplinarity of mathematics and science especially on relations of chemistry and mathematics. The interdisciplinary approach to education in schools is a necessary condition for further complex problem-solving of everyday issues in professional life.

\section{Research methodology}

\subsection{Interview}

To pinpoint the areas of education content of chemistry that are the most problematic for the high-school students, we used the method of personal interviews with qualified high-school teachers of mathematics, chemistry and science. Our investigation currently includes 11 interviews.

According to the answers of the interviewees the students are able to comprehend the definition of a certain chemical phenomenon but are unable to describe it and formally or graphically express the steps of the solution. In other words students cannot apply their mathematical skills to interdisciplinary problem-solving and make the correct conclusions in chemistry. For us it is the main reason to put our efforts into creating sets of materials and educational tasks appropriate for acquiring the skills for development of scientific and visual literacy.

\subsection{Item analysis of tests}

An extensive testing of knowledge and skills of high-school students in chemistry was conducted in Czech Republic in 2014 and 2015 [8]. Item analysis of this testing was second source for our research. The evaluation of analysis revealed the difficulties in the procedures of solutions and discovered the most difficult parts of the logical thought processes of students. The sample range of tested students was 1079 overall, 396 students have taken the test in general chemistry, 337 in inorganic chemistry, 243 in organic chemistry and 103 in biochemistry. The sample was composed of 656 girls and 423 boys.

The areas of close connections between chemistry and mathematics have been determined according to this analysis. The first step to successfully solve every task is to 
choose the appropriate part of the mathematical apparatus. The revealed connections are summarized in the Table 1. The mathematical skills are divided into four basic groups.

Table 1. Mathematical skills and their applications in chemistry

\begin{tabular}{|c|c|}
\hline Mathematical skill & Application in chemistry \\
\hline $\begin{array}{l}\text { Application of algebraic } \\
\text { calculations }\end{array}$ & $\begin{array}{l}\text { - Use of direct and reverse proportion in general chemistry } \\
\text { calculations, mass fraction, solution concentration } \\
\text { - Determining the stoichiometry of a reaction } \\
\text { - Expressing an unknown from a physical chemistry formula }\end{array}$ \\
\hline $\begin{array}{l}\text { Spatial imagination and the } \\
\text { use of geometry and } \\
\text { stereometry }\end{array}$ & $\begin{array}{l}\text {-Determining the structure of molecules and crystals } \\
\text { - Modelling and construction of structural particles } \\
\text { - Graphical interpretation of structures and formulae }\end{array}$ \\
\hline $\begin{array}{l}\text { Analytical logical thinking, } \\
\text { charted and tabled data } \\
\text { interpretation }\end{array}$ & $\begin{array}{l}\text {-Identification of a compound according to given properties } \\
\text { - Plotting a graph out of experimental measurements } \\
\text {-Practical application of laws of physical chemistry }\end{array}$ \\
\hline $\begin{array}{l}\text { Application of functional } \\
\text { analysis }\end{array}$ & $\begin{array}{l}\text { - Spatial shapes of orbitals and bond formation } \\
\text { - Functional dependencies of quantities in physical chemistry }\end{array}$ \\
\hline
\end{tabular}

The logical thinking in chemical interpretation of conclusions gained during the problem-solving is the essential prerequisite for the inquiry-based approach to education. The scientific thinking has to be unconditionally based on applications of mathematical procedures and logical thought processes.

\subsection{Follow-up testing}

The preliminary research was the basis for creation of the follow-up test that should prove the assumptions made from previous conclusions. To verify our ideas we conducted a smaller survey in 2017. The sample range of this local survey (in Prague) was 104 students. This new test consists of 14 chemical tasks focused on the areas that naturally and appropriately require the usage of mathematics to comprehend the chemical principles and vice versa. Certain inquiry procedure, logical deliberation or mathematical skill and knowledge were necessary to solve each of the test items. The validity of the new test was discussed and verified by independent competent high-school teachers and academics.

The test was taken by two groups of students. One group consists of 73 high-school students in the last year of their studies (so they have the knowledge about the whole chemical curriculum) the second group are the first year university students of bachelor studies in chemistry teaching, molecular biology and general biology. Number of university students was only 31 .

The results of the testing can be summarized in a few conclusions. Overall it is certain that the success rate of high-school students is higher than the university students. The main reason for this strange outcome could be the factor of forgetting, but also insufficient interdisciplinary connection between mathematics and science subjects and logical applications of knowledge and skills in science into practical problems. The interest of the students in the subject of chemistry could also be next reason for the difference between the high-school students and university students. The analysis of test items has shown the main differences between the two groups of tested students (see Table 2).

Table 2. Comparison of results between groups of students

\begin{tabular}{|c|c|c|c|c|c|c|c|}
\hline & 3.3.1 & 3.3 .2 & 3.3.3 & \multicolumn{2}{|c|}{ 3.3.4 } & \multicolumn{2}{|c|}{3.3 .5} \\
\hline High school & $\begin{array}{c}56 \% \\
16 \% \text { EoI }\end{array}$ & $48 \%$ & $26 \%$ & $\begin{array}{c}78 \% \\
\text { GC }\end{array}$ & $\begin{array}{c}84 \% \\
\text { BC }\end{array}$ & $\begin{array}{l}77 \% \text { (models of } \\
\text { structures) }\end{array}$ & $\begin{array}{c}69 \% \\
\text { (allotropes) }\end{array}$ \\
\hline $\begin{array}{l}\text { University } \\
\text { students }\end{array}$ & $\begin{array}{c}22 \% \\
39 \% \text { EoI }\end{array}$ & $17 \%$ & $0 \%$ & $\begin{array}{c}61 \% \\
\text { GC }\end{array}$ & $\begin{array}{c}78 \% \\
\text { BC }\end{array}$ & $\begin{array}{l}70 \% \text { (models of } \\
\text { structures }\end{array}$ & $\begin{array}{c}0 \% \\
\text { (allotropes) }\end{array}$ \\
\hline
\end{tabular}




\subsubsection{Comprehensive reading}

$16 \%$ of high-school students and $40 \%$ of university students have not read the instruction properly and so they have solved the task only partially, although their procedure of solving the task was correct (errors of inattention EoI - see Table 2).

\subsubsection{Logical reasoning using mathematical principle of a concept in physical chemistry}

$48 \%$ of high-school students and only $17 \%$ of university students have solved the task concerning half-life of radionuclide. This task can be solved by simple logical mathematical reasoning or using the exponential function.

\subsubsection{Data analysis and evaluation}

$26 \%$ of high-school students were able to analyse the data from a chart to determine the formula of an organic compound according to the results of a certain set of chemical reactions. The students from university have not solved the task properly at all and only $9 \%$ of the students have solved the task at least partially. This task demonstrates the lack of ability of students to logically connect chemical knowledge with data interpretation.

\subsubsection{Interpretation of tabulated data}

The success rate of tasks concerning the reading with comprehension of data from charts were different depending on the area of chemistry. Overall success rate of the task in biochemistry (BC - see Table 2) was higher than the success rate of a similar task in general chemistry. The task concerning about the finding out the proper sequence of amino acids depending on the sequence of nucleotides in m-RNA according to the codon table was solved successfully by $78 \%$ of university students and $84 \%$ of high school students. This proves the sufficient knowledge and ability to work with the tabulated biochemical data and also a good connection with the knowledge of biology. Similar task in the area of general chemistry (GC -see Table 2) concerning the ionisation energy of elements was successfully solved by $61 \%$ of university students and $78 \%$ of high-school students. The success rate in general chemistry task is lower.

\subsubsection{Structure of compounds and spatial imagination}

Spatial imagination about the shapes of molecules and structures of chemical compounds is sufficient in both groups (success rate of high-schools students was $77 \%$ and success rate of university students from university was $77 \%$ ). A similar task about the allotropes of the carbon had a similar success rate in high-school group. The university student group had much lower success rate (complete solution $-0 \%$, partial solution $-35 \%$ ). The task that requires the comprehension and application of knowledge of chemical structures had a higher success rate than the task that required simple remembering of terms about the spatial structure.

\section{Possible system solutions of survey issues}

There are two main approaches to solve the problem that was uncovered by our research. These solutions are not mutually exclusive, on the contrary their effectiveness is based on 
their synergy. Synergy could be defined as a wholesome approach to problem solution in which the sum of effects of individual parts is lesser than the whole effectiveness [9].

\subsection{Change of curriculum}

The first of the possibilities is a system change of the subject curricula. This change could concern the logical arrangement, appropriate selection and modification of the subject content. The newly gained knowledge of content in different subjects has to be in a mutual logical correspondence. This approach requires the team collaboration among the teachers of related science subjects with mathematics and interdisciplinarity in every area of education. The topics in science subjects should logically connect to the corresponding theoretical mathematical skills.

\subsection{Educational materials}

The second part of the proposed solution is to create educational materials and make the available to the teachers via the educational websites. The created materials are supposed to naturally accent the connections between mathematics, chemistry, physics, biology and science in general. The inquiry-based science education (IBSE) is the most suitable method for this interdisciplinary approach.[10]

Our educational materials include worksheets containing interdisciplinary and inquirybased educational tasks for students. The worksheets are accompanied by the methodological commentary for teachers. The materials are being used and verified in common high-school education during this school year.

One of the worksheets concerns about chemical structure. The pupils are supposed to discover the structure of molecules of simple inorganic compounds and elements (see Figures 1-3).
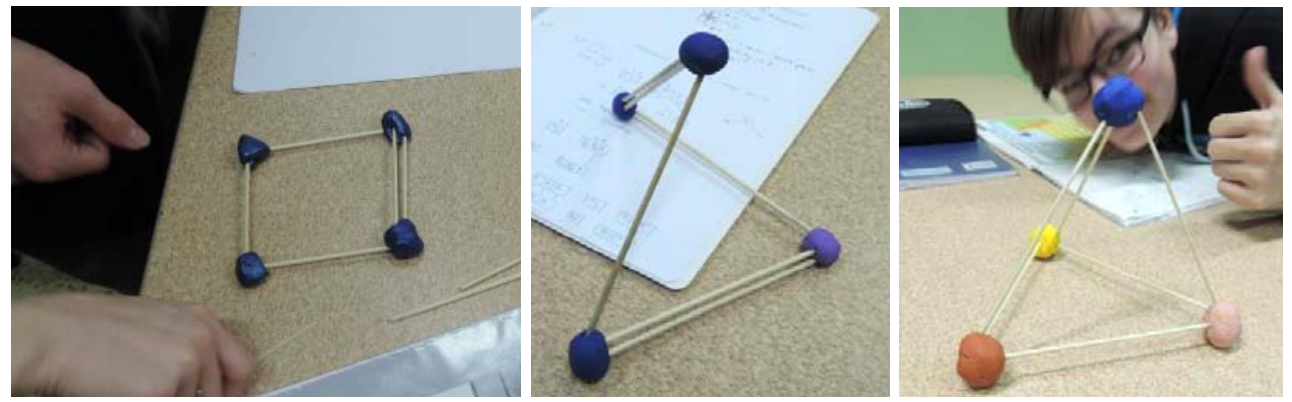

Fig. 1-3 Models of $\mathrm{P}_{4}$ molecules created by students (including the misconceptions) - modelling clay and skewers

Similar activities concerning about the structure of simple organic compounds can be seen in Fig. 4-5. The students were independently creating and inquiring about the tetrahedral structure of organic and inorganic molecules. The Figure 4 shows the process of creation of correct arrangement of atoms in tetrahedral structure of methane. The Figure 5 shows the similarity in structures of molecules of white phosphorus $\left(\mathrm{P}_{4}\right)$ and methane $\left(\mathrm{CH}_{4}\right)$. 

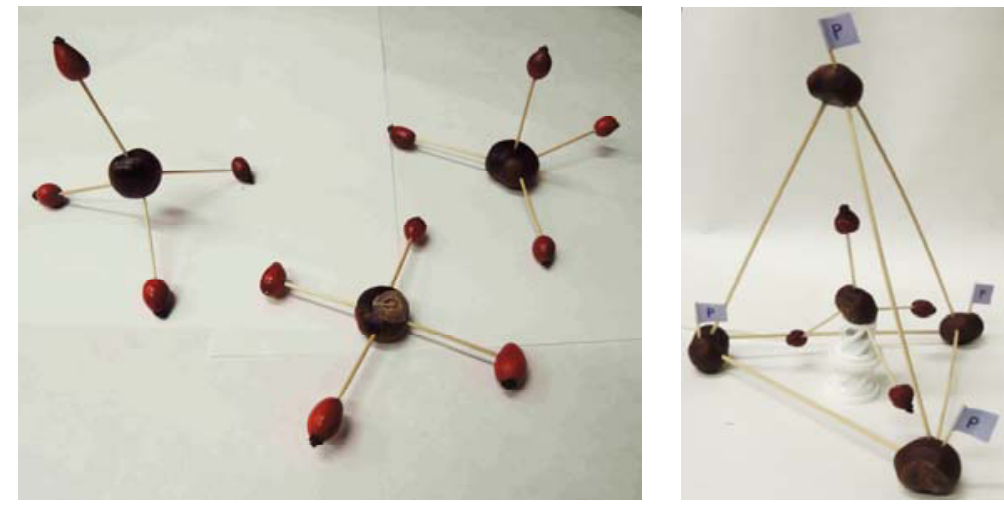

Fig. 4-5 Models of molecules (including the misconceptions) $\mathrm{CH}_{4}$ and $\mathrm{P}_{4}-$ chestnuts, rosehips, toothpicks and skewers.

The other worksheets concern about the mathematical modelling of physical-chemistry phenomenon - the disintegration of nuclei of radionuclides. The pupils use coin-tossing as a way to model this phenomenon. Fig. 6-7 shows the activity and its' evaluation and statistical analysis performed by students.
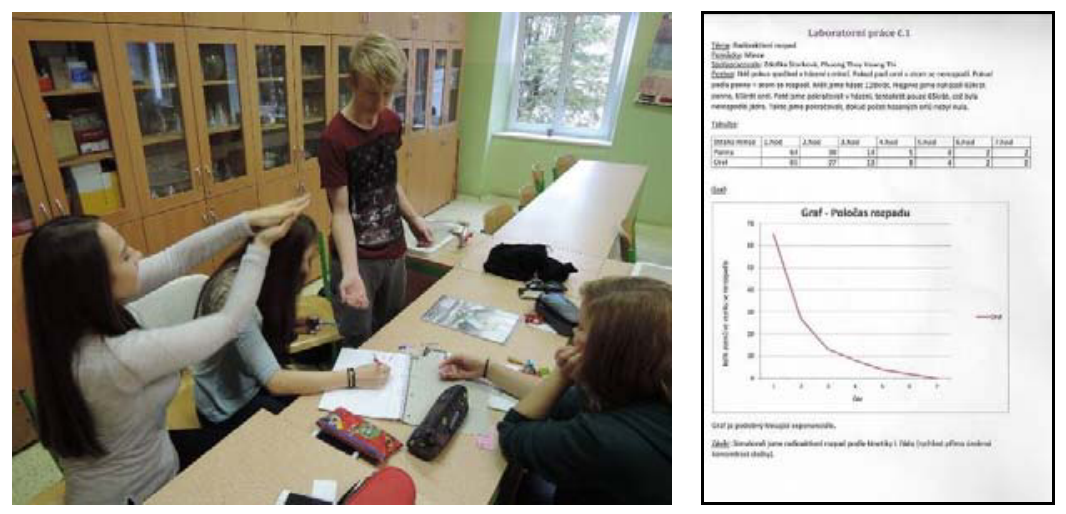

Fig. 6-8 Coin-tossing and evaluation of results

\section{Conclusion}

The research of using the mathematical principles in chemistry has lead us to the idea of rearranging the parts of chemistry curriculum so the explanation of the phenomena in chemistry would be easier. This requires cooperation of high-school teachers of related fields during the creation of the school curriculum. At the same time it is necessary to create appropriate education materials that accent and support the interdisciplinary approach to education. These materials should simplify the process of preparation of lessons by the teachers. The methods most suitable for this approach are project-based education, inquiry-based education and other methods of active student learning. It will be easier for the teachers of science without focus on the mathematics to implement the mathematical principles into solving the practical educational tasks.

Nowadays, the effectivity of our created materials has been verified with the highschool students in common lessons during this school year. 


\section{Acknowledgement}

This work is supported by research project PROGRESS Q 46.

\section{References}

1. D. Kuhn, S. Pearsall Journal of Cognition and Development 1, 113-129, (2000)

2. J. Bečvář Matematika Aktivně, aktuálně a s aplikacemi, 43-60, (P3K, Praha, 2012)

3. V. Lamanuskas Problems of Eduation in the 21st century 62, 5-7, (2014)

4. S. Karaçam, V. Bilir, A. D. Baran, ERPA 4, 129-134, (2016)

5. M. Nodzyńska Wizualizacja w chemii $i$ nauczaniu chemii (Wydawnictwo naukove Uniwersytetu Pedagogicznego, Kraków, 2012)

6. M. Bílek Vybrané aspekty vizualizace učiva př́rodovédných předmětů (M\&V, Hradec Králové, 2007)

7. A. Šarounová Matematika Aktivně, aktuálně a s aplikacemi, 5-24, (P3K, Praha, 2012)

8. R. Šulcová, T. Cífková BECH 20(4), 11-18 (2016)

9. R. B. Fuller Synergetics: Explorations In The Geometry Of Thinking. (Macmillan Publishing Company, Inc., New York, 1975)

10. R. Šulcová, M. Ivan Aktuální aspekty pregraduálne př́pravy a postgraduálního vzdělávání učitelů chemie (Ostravská univerzita, 2017) 